\title{
REFERENCES
}

Andrewes, C. H., van den Ende, M., King, H. \& Walker, J. (1944). Lancet, 1, 777.

Devine, J. (1944). Ann. trop. Med. Parasit. 38, 35.

Ekeley, J. B. \& Ronzio, A. R. (1935). J. Amer. chem.Soc. 57, 1353.
Ekeley, J. B. \& Ronzio, A. R. (1937). J. Amer. chem. Soc. 59, 1313.

Evans, D. G., Fuller, A. T. \& Walker, J. (1944). Lancet, 2, 523.

\section{The Amylase and Maltase of Clostridium acetobutylicum}

\author{
By D. J. D. HOCKENHULL AND D. HERBERT, Medical Research Council Unit \\ for Chemical Microbiology, the Biochemical Laboratory, Cambridge
}

(Received 8 November 1944)

This work concerns the degradation of starch to glucose by enzymes of Clostridium acetobutylicum, a stage in the butanol-acetone fermentation which has so far been little investigated. Previous workers have mainly used growing cultures of $\mathrm{Cl}$. acetobutylicum, though Robinson (1922) showed that starch (and other carbohydrates) were fermented by toluene-treated cell suspensions. In the present work we have used cell-free enzyme preparations obtained from culture filtrates of $\mathrm{Cl}$. acetobutylicum (Weizmann). If the organism be grown in media containing maltose as the only carbohydrate, the culture filtrates contain a maltase but have no starch-splitting activity; if grown in media containing starch, culture filtrates contain both a maltase and an amylase. The properties of both these enzymes have been studied, and the amylase has been partially purified.

\section{METHODS}

Estimation of reducing sugars. The activities of both enzymes were followed by measurement of the reducing groups set free by their action, using a modification (C. S. Hanes, unpublished) of the method of Somogyi (1937).

Solution $A$ is made by dissolving $50 \mathrm{~g}$. anhyd. $\mathrm{Na}_{2} \mathrm{CO}_{3}$, 25 g. Rochelle salt, $7 \cdot 5 \mathrm{~g}$. $\mathrm{CuSO}_{4} \cdot 5 \mathrm{H}_{2} \mathrm{O}, 160 \mathrm{~g}$. anhyd. $\mathrm{Na}_{2} \mathrm{SO}_{4}$ and $1.5 \mathrm{~g}$. KI, in the order given, in $750 \mathrm{ml}$. boiling distilled water; on cooling, $0.75 \mathrm{~g}$. $\mathrm{KIO}_{3}$ is added and the volume made up to 11 . It is stored at $37^{\circ}$.

Solution $B$ is a mixture of equal volumes of $5 \% \mathrm{KI}$ and $5 \%$ neutral potassium oxalate, mixed immediately before use.

The tinknown solution ( $5 \mathrm{ml}$.), containing up to $3 \mathrm{mg}$. maltose or $1.5 \mathrm{mg}$. glucose, is heated with $5.0 \mathrm{ml}$. of solution $A$ in a boiling water-bath for $15 \mathrm{~min}$. After rapid cooling to room temperature, $2 \mathrm{ml}$. solution $\mathrm{B}$, followed by $3 \mathrm{ml} .2 \mathrm{~N}-\mathrm{H}_{2} \mathrm{SO}_{4}$, are added; the solution is allowed to stand 3 min., and titrated with $0.01 \mathrm{M}-\mathrm{Na}_{2} \mathrm{~S}_{2} \mathrm{O}_{3}$, with $1 \%$ starch in saturated $\mathrm{NaCl}$ as indicator.

The calibration figures for maltose and glucose are:

\begin{tabular}{clllllll}
$\begin{array}{c}\text { Titre (ml. of } \\
\left.\text { 0.01 M- } \mathrm{Na}_{2} \mathrm{~S}_{2} \mathrm{O}_{3}\right)\end{array}$ & \multicolumn{5}{c}{ Amount of sugar taken (mg.) } \\
with & $\overbrace{0.5}$ & 1.0 & 1.5 & 2.0 & 2.5 & 3.0 & 3.5 \\
(a) for maltose & 0.92 & 1.92 & 2.91 & 3.90 & 4.91 & 5.97 & 7.05. \\
(b) for glucose & 1.78 & 3.62 & 5.53 & 7.47 & - & - &.-
\end{tabular}

\section{Measurement of amylase activity}

Reduction method. We define 1 reduction unit of amylase activity es that amount of enzyme which produces reducing substances equivalent to $7.5 \mathrm{mg}$. maltose in $30 \mathrm{~min}$. at $37^{\circ}$, when allowed to act on $2 \mathrm{ml}$. $1 \%$ soluble starch and $1 \mathrm{ml}$. M-acetate buffer of $\mathrm{pH} \mathrm{4.6}$, in a total volume of $4 \mathrm{ml}$. Mixtures were deproteinized by the method of Somogyi (1931) and reducing sugar in a portion of the filtrate determined by the above technique. Since the amount of reducing sugar produced is not a linear function of the enzyme concentration (Fig. 4), the number of reduction units of enzyme in an unknown solution is found by interpolation from this standard curve.

Iodine colour method. Cl. acetobutylicum amylase brings about the conversion of starch to substances giving no colour with iodine. Suitably diluted enzyme solution ( $2 \mathrm{ml}$.) is mixed with $1 \mathrm{ml}$. $1 \%$ soluble starch and $1 \mathrm{ml}$. M-acetate buffer (pH 4.6) and incubated at $37^{\circ}$. Samples are withdrawn at intervals and tested with iodine, and the time taken to reach the 'achromic point' noted. The iodine-colour unit of amylase activity is defined as the amount of enzyme which reaches the achromic point in $1 \mathrm{hr}$. under the above conditions. Up to an enzyme concentration of 20 units, the time taken to reach the achromic point is inversely proportional to the enzyme concentration.

The iodine colour method is more convenient than the reduction method, and though less accurate, is useful for preliminary experiments. When the same enzyme solution is measured by both methods, it is found that 1 reduction unit $=7 \cdot 1$ iodine-colour units.

\section{Measurement of maltase activity}

We define one maltase unit as the amount of enzyme bringing about the hydrolysis of $5 \mathrm{mg}$. maltase in $1 \mathrm{hr}$. at $37^{\circ}$, when allowed to act on $2 \mathrm{ml} .1 .5 \%$ maltose and $1 \mathrm{ml}$. $0 \cdot 2 \mathrm{M}$-acetate buffer of $\mathrm{pH} \mathrm{4.25}$, in a total volume of $6 \mathrm{ml}$. The methods used for deproteinization and measurement of reducing substances were as previously described. The relationship between enzyme concentration and maltose hydrolyzed is linear over the range $0.5-1.5$ maltase units.

\section{RESULTS}

\section{The maltase of $\mathrm{Cl}$. acetobutylicum}

Preparation of the maltase. Culture filtrates of Cl. acetobutylicum grown in a maize-meal medium 
contain a maltase associated with an amylase. Grown in a yeast-autolysate medium with maltose as sole source of carbohydrate, the organism produces only maltase. When grown in yeast-autolysate medium with glucose or sucrose as carbohydrate source, neither the maltase nor the amylase is produced. Less maltase was produced in the yeastautolysate-maltose medium than in the maize-meal medium, but the former medium had the advantage that it contained less protein impurities.

Active enzyme preparations were obtained as follows :

Two 1. of $1 \%$ yeast autolysate medium (Weizmann \& Rosenfeld, 1937), containing $2 \%$ maltose and adjusted to pH 7.0, were inoculated with $20 \mathrm{ml}$. of a $40 \mathrm{hr}$. maize-meal culture of $\mathrm{Cl}$. acetobutylicum (Weizmann), incubated $60 \mathrm{hr}$. at $37^{\circ}$, centrifuged, and filtered through paper-pulp. The filtrate was concentrated in vacuo (below $35^{\circ}$ ) to $60-70 \mathrm{ml}$., dialyzed for $24 \mathrm{hr}$., and insoluble material removed by centrifuging. The water-clear, pale yellow supernatant had an activity of $c$. 1 maltase-unit/ml., and a dry weight of c. $15 \mathrm{mg} . / \mathrm{ml}$. Treatment with tricalcium phosphate gel, which adsorbed a good deal of protein impurity but no enzyme, brought about further purification.

The same method was used for the enzyme produced in maize-meal medium; the maltase had the same properties in either case.

Properties of the maltase. The $\mathrm{pH}$-activity curve (Fig. 1) of the maltase shows the pH optimum at 4.5, which is approximately the final $\mathrm{pH}$ of a fermenting maize-meal culture.

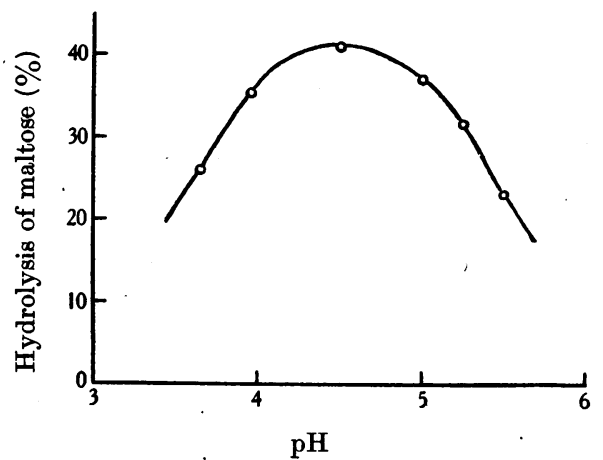

Fig. 1. Effect of $\mathrm{pH}$ on maltase activity. $2 \mathrm{ml}$. enzyme, $2 \mathrm{ml} .1 \cdot 5 \%$ maltose, $1 \mathrm{ml} .0 \cdot 2 \mathrm{M}$-acetate buffer and $1 \mathrm{ml}$. water incubated 60 min. at $37^{\circ}$.

The velocity of hydrolysis by the maltase is maximal at a maltose concentration of $0.02 \mathrm{M}$; the half-speed concentration is $0.0016 \mathrm{M}$. There is a linear relationship between enzyme concentration and velocity of hydrolysis up to enzyme concentrations of 1.5 units $/ \mathrm{ml}$. Fig. 2 shows a progress curve. After $4 \mathrm{hr}$. incubation, the reducing substances liberated reached $96 \%$ of the theoretical amount calculated for complete conversion of maltose to glucose. That the action of the enzyme is the splitting of one molecule of maltose to two molecules of glucose was confirmed by the isolation of glucosazone.

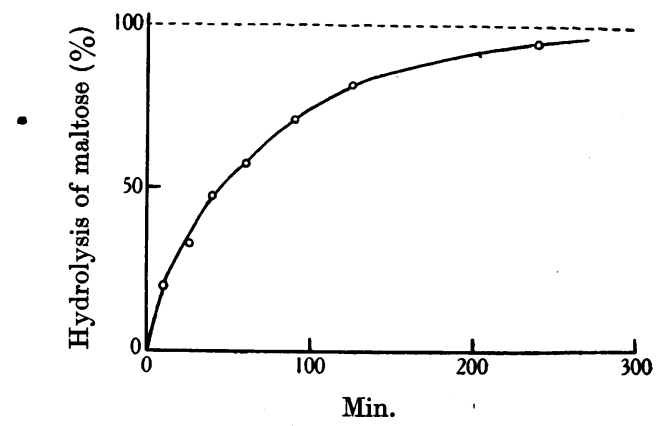

Fig. 2. Progress curve of maltose hydrolysis. $9 \mathrm{ml}$. enzyme, $6 \mathrm{ml} .1 \cdot 5 \%$ maltose and $3 \mathrm{ml} .0 \cdot 2 \mathrm{M}$-acetate buffer $\mathrm{pH} 4.23$ incubated at $37^{\circ}$; samples withdrawn at intervals.

$100 \mathrm{ml}$. of $6 \%$ maltose were incubated at $37^{\circ}$ with $50 \mathrm{ml}$. enzyme in $\mathrm{M} / 3$ acetate buffer (pH 4.6) until hydrolysis was complete $(96 \mathrm{hr}$.). The solution was evaporated to dryness under reduced pressure, and extracted with two $50 \mathrm{ml}$. portions of boiling $90 \%$ ethanol. The extracts were evaporated to dryness, taken up in $50 \mathrm{ml}$. water, and the phenylosezone isolated in the usual way. Yield 6 g.; recrystallized twice from ethanol, m.p. $207^{\circ}$; m.p. of authentic glucosazone $208^{\circ}$; mixed m.p. $207^{\circ}$. Found: C, $61 \cdot 3 ; \mathrm{H}, 6 \cdot 2 ; \mathrm{N}, 15 \cdot 3 \%$. Calc. for $\mathrm{C}_{18} \mathrm{H}_{22} \mathrm{O}_{4} \mathrm{~N}_{4}$ : C, 60.2; $\mathrm{H}, 6 \cdot 15 ; \mathrm{N}, 15 \cdot 6 \%$.

The enzyme thus appears to be a typical maltase, differing from other maltases (e.g. yeast, pancreatic) only in its considerably more acid optimum pH. It appears to be a specific maltase and not an $\alpha$-glucosidase, since it does not hydrolyze other $\alpha$-glucosides such as sucrose.

\section{The amylase of $\mathrm{Cl}$. acetobutylicum}

Purification of the amylase. $4 \mathrm{l}$. of $5 \%$ maize-meal suspension, sterilized by autoclaving for $2 \mathrm{hr}$. at $120^{\circ}$, was rapidly cooled to $37^{\circ}$, inoculated with $40 \mathrm{ml}$. of a $48 \mathrm{hr}$. culture of $\mathrm{Cl}$. acetobutylicum in the same medium, and incubated at $37^{\circ}$ for $40 \mathrm{hr}$. The culture was centrifuged and filtered through kieselguhr, giving c. 3.6 l. of clear yellow liquid (stage 1) which was concentrated in vacuo (below $35^{\circ}$ ) to $200-250 \mathrm{ml}$. The brown, sticky concentrate (stage 2) was dialyzed for a few hours against running tap water; the dialysis sac was then transferred to a beaker and packed with solid $\left(\mathrm{NH}_{4}\right)_{2} \mathrm{SO}_{4}$ and left for $16 \mathrm{hr}$. The contents of the dialysis sac were centrifuged and the supernatant layer discarded. The dark brown, sticky precipitate was taken up in a minimum amount of water, dialyzed against glassdistilled water overnight, and insoluble material removed by centrifuging, giving c. $100 \mathrm{ml}$. of supernatant liquid (stage 3).

The next step was adsorption of the enzyme on starch (cf. Holmbergh, 1933; Tokuoka, 1937). Adsorption is favoured by fairly high concentrations 
of ethanol and inhibited by salts; in the complete absence of salts, however, the enzyme is unstable to $50 \%$ ethanol, so that sufficient salts must be added to stabilize the enzyme without hindering adsorption. -
Fig. 4 shows that the amounts of reducing substances produced by varying amounts of enzyme in $30 \mathrm{~min}$. are not strictly proportional to the amount of enzyme, being relatively less with higher enzyme concentrations. Consequently, Fig. 4 must be used

Table 1. Purification of amylase

\begin{tabular}{|c|c|c|c|c|c|c|}
\hline \multirow[b]{2}{*}{ Stage } & \multicolumn{4}{|c|}{ Amylase activity } & \multirow[b]{2}{*}{$\begin{array}{c}\text { Iodine } \\
\text { units } / \mathrm{mg} . \\
\text { dry matter }\end{array}$} & \multirow[b]{2}{*}{$\frac{\text { Amylase units }(a)}{\text { Maltase units }}$} \\
\hline & $\underset{\text { (ml.) }}{\text { Volume }}$ & $\begin{array}{c}(a) \\
\text { (iodine } \\
\text { units/ml.) }\end{array}$ & $\begin{array}{c}\text { (b) } \\
\text { (reduction } \\
\text { units/ml.) }\end{array}$ & $\begin{array}{l}\text { Ratio } \\
(a) /(b)\end{array}$ & & \\
\hline $\begin{array}{l}1 \\
2 \\
3 \\
4\end{array}$ & $\begin{array}{r}3600 \\
250 \\
100 \\
25\end{array}$ & $\begin{array}{r}0 \cdot 6 \\
8 \cdot 3 \\
15 \cdot 7 \\
48 \cdot 0\end{array}$ & $\begin{array}{l}\overline{1 \cdot 17} \\
2 \cdot 16 \\
6 \cdot 8\end{array}$ & $\begin{array}{l}\overline{7 \cdot 1} \\
7 \cdot 26 \\
7 \cdot 08\end{array}$ & $\begin{array}{c}0.04 \\
0.04 \\
0.36 \\
11.7\end{array}$ & $\begin{array}{r}\overline{0.9} \\
2 \cdot 9 \\
16.5\end{array}$ \\
\hline
\end{tabular}

To the dialyzed solution (stage 3 ), $\mathrm{Na}_{2} \mathrm{SO}_{4}$ was added to make $1 \%$, and the solution cooled in ice; an equal volume of cooled ethanol was added and an insoluble precipitate (mostly polysaccharides) centrifuged off. One mI. of a $12.5 \%$ suspension of potato starch in $50 \%$ ethanol was added to each $10 \mathrm{ml}$. of supernatant, and adsorption allowed to take place for $2 \mathrm{hr}$. at $0^{\circ}$, with frequent shaking. The starch was centrifuged off and the amylase eluted from it with two successive $10 \mathrm{ml}$. portions of $0.04 \mathrm{M}$-phosphate of pH 5.8. Both elutions were carried out at $37^{\circ}$, with frequent stirring, for $20 \mathrm{~min}$., and the combined eluates thoroughly dialyzed (stage 4).

Table 1 gives details of purification and yields at each stage of a typical preparation, the final purification being 300 -fold, with a $58 \%$ yield. The purification process removes c. $95 \%$ of the accompanying maltase, but it could not be removed completely. Solutions of the purified enzyme are stable for some weeks at $0^{\circ}$. They may be dried from the frozen state without loss of activity; the dried product is stable for long periods.

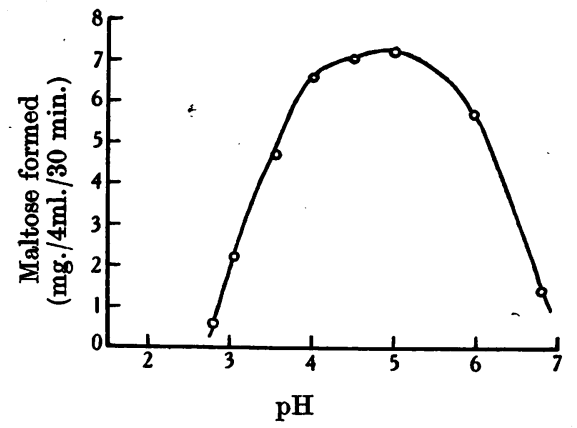

Fig. 3. Effect of $\mathrm{pH}$ on amylase activity (reduction method). $1 \mathrm{ml}$. enzyme, $1 \mathrm{ml}$. 0.5 M-phosphate-citrate buffers of varying $\mathrm{pH}$ and $2 \mathrm{ml} .1 \%$ soluble starch incubated 30 min. at $37^{\circ}$.

Properties of the amylase. The $\mathrm{pH}$-activity curve, measured by the reduction method, shows a pH optimum at 4.8 (Fig. 3). The enzyme has the same activity in acetate and citrate-phosphate buffers of the same $\mathrm{pH}$. as a calibration curve when the activity of an enzyme solution of unknown strength is to be measured.

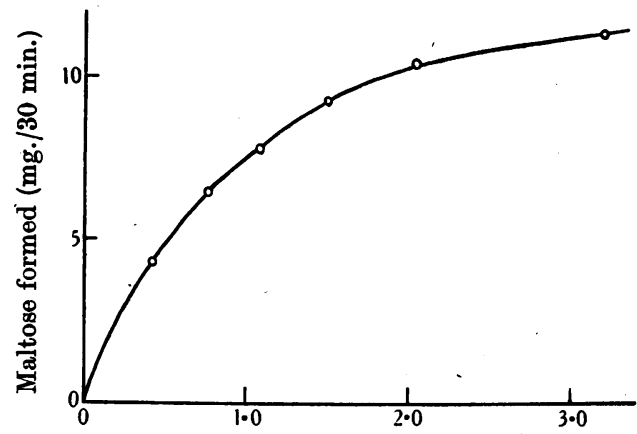

Amylase concentration (reduction units/4 ml.)

Fig. 4. Effect of enzyme concentration on amylase activity by reduction method. $1 \mathrm{ml}$. M-acetate buffer $\mathrm{pH} 4 \cdot 63$, $2 \mathrm{ml} .1 \%$ soluble starch and varying amounts of enzyme incubated $30 \mathrm{~min}$. at $37^{\circ}$ in a total volume of $4 \mathrm{ml}$.

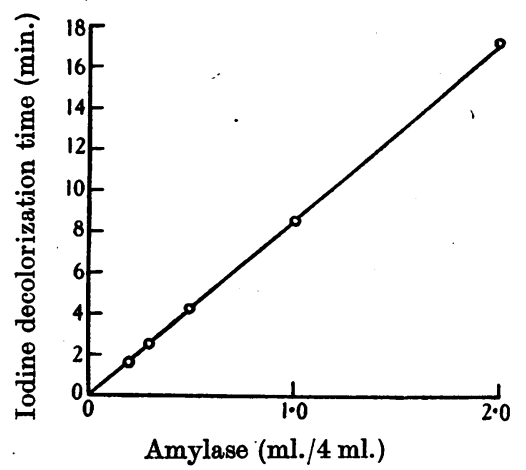

Fig. 5. Effect of enzyme concentration on amylase activity by iodine-colour method. $1 \mathrm{ml}$. M-acetate $\mathrm{pH} \mathrm{4.63,} 1 \mathrm{ml}$. $1 \%$ soluble starch and varying amounts of enzyme, in a total volume of $4 \mathrm{ml}$., incubated at $37^{\circ}$ until iodine colour disappeared.

Fig. 5 shows the effect of enzyme concentration measured by the iodine-colour method. While the 
reduction method measures the amount of change occurring in a given time, the iodine-colour method measures the time required to effect a certain change; in this case the time is inversely proportional to enzyme concentration over a wide range.

The velocity of hydrolysis (reduction method) reaches a maximum at a starch-concentration of $7.5 \mathrm{mg} . / \mathrm{ml}$; the half-speed concentration is $2.08 \mathrm{mg}$./ml. (Fig. 6). The time taken to hydrolyze

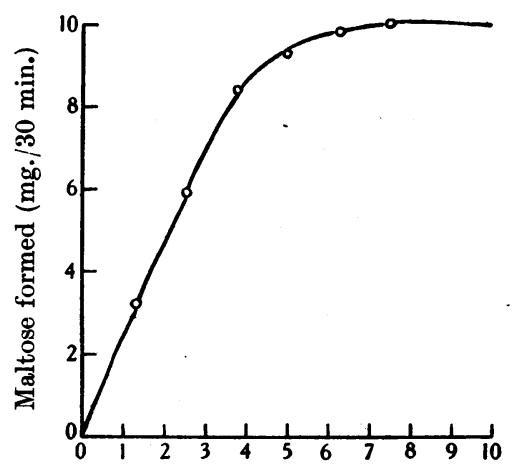

Initial starch concentration (mg./ml.)

Fig. 6. Effect of starch concentration on amylase activity by reduction method. $1 \mathrm{ml}$. enzyme, $1 \mathrm{ml}$. M-acetate pH 4.63 and $2 \mathrm{ml}$. starch solutions of varying concentration, incubated $30 \mathrm{~min}$. at $37^{\circ}$.

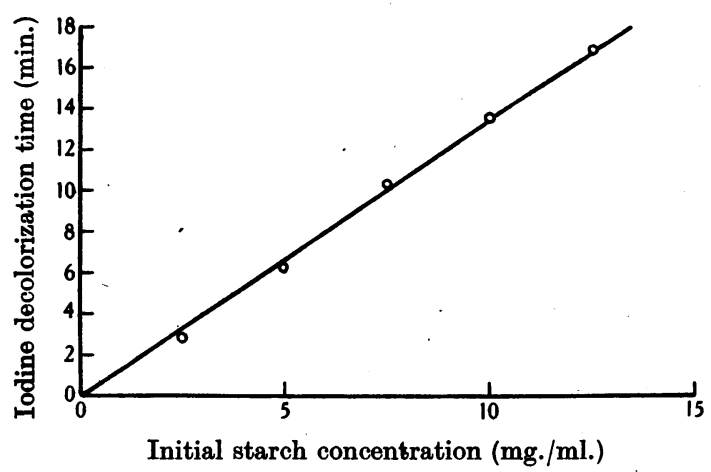

Fig. 7. Effect of starch concentration on iodine-decolorization time. $1 \mathrm{ml}$. enzyme, $1 \mathrm{ml}$. $\mathrm{m}$-acetate $\mathrm{pH} \mathrm{4.63}$ and $2 \mathrm{ml}$. starch solutions of varying concentration, incubated at $37^{\circ}$ until iodine colour disappeared.

varying amounts of starch, however, as measured by the iodine-colour method, is directly proportional to the starch concentration (Fig. 7).

Unlike some amylases, the amylase of $\mathrm{Cl}$. acetobutylicum is not activated by chloride or phosphate ions. None of the following substances: KCN, $\mathrm{MgCl}_{2}, \mathrm{NaF}, \mathrm{NaH}_{2} \mathrm{AsO}_{4}$, iodoacetate, phlorrhizin, maltose, inulin, cysteine and catechol, had any effect on the enzyme in concentrations up to $0.01 \mathrm{M}$. $\mathrm{CuSO}_{4}$ in concentrations of 0.001 and $0.0001 \mathrm{M}$ gave 95 and
$60 \%$ inhibition respectively. Ascorbic acid and dihydroxymaleic acid $(0.01 \mathrm{M})$ gave 92 and $88 \%$ inhibition respectively, the inhibition being reversed by $0.02 \mathrm{~m}-\mathrm{KCN}$. These effects are exactly similar to those found by Hanes (1935) for malt amylase. Dextrin and glycogen are both hydrolyzed by the enzyme, though more slowly than starch; inulin is not attacked (Table 2).

\section{Table 2. Action of the amylase on various polysaccharides}

(1 ml. purified enzyme incubated $30 \mathrm{~min}$. at $37^{\circ}$ with $1 \mathrm{ml}$. M-acetate buffer, pH 4.63, and $2 \mathrm{ml} .1 \%$ substrate.)

Reducing substances

$\begin{array}{lr}\text { Substrate } & \text { liberated, calc. } \\ \text { (mg.) } \\ \text { Starch } & 10 \cdot 9 \\ \text { Dextrin } & 6 \cdot 0 \\ \text { Glycogen } & 6 \cdot 4 \\ \text { Inulin. } & 0 \cdot 0\end{array}$

Mode of action of the amylase on starch and the nature of the end-products

Fig. 8 shows progress curves of $(a)$ a crude amylase preparation of high maltase content and $(b)$ a purified amylase of low maltase content, both solutions

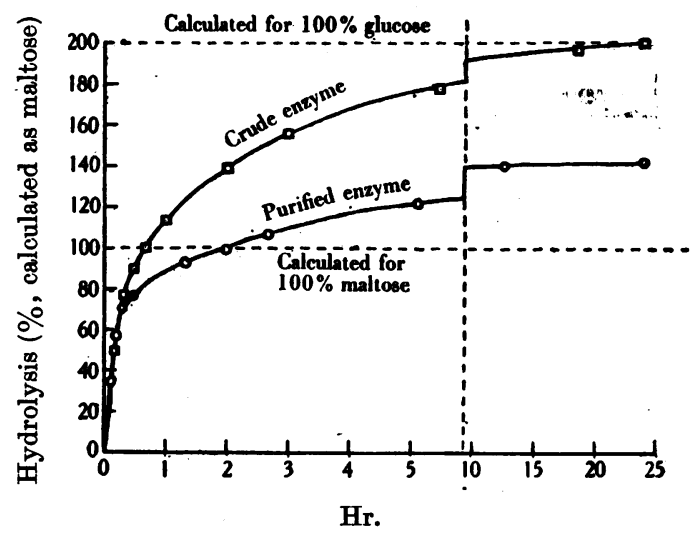

Fig. 8. Progress-curves of crude and purified amylase. $5 \mathrm{ml}$. enzyme, $5 \mathrm{ml}$. M-acetate pH 4.63 and $10 \mathrm{ml} .1 \%$ starch incubated at $37^{\circ}$; samples withdrawn at intervals for estimation of reducing substances. Ratio of amylase activity/maltase activity $=\mathbf{2 . 9}$ for crude enzyme, 16.5 for purified enzyme.

containing 50 amylase units $/ \mathrm{ml}$. In the early stages of the reaction, until about $70 \%$ of the theoretical reducing groups (calculated as maltose) had been liberated, the two curves were identical; thereafter they diverged, and while the low maltase preparation slowed down markedly after reducing groups equivalent to $100 \%$ maltose had been liberated, the high maltase preparation proceeded to convert the starch $100 \%$ into glucose. This strongly suggests 
that the action of a completely maltase-free amylase would cease altogether after reducing groups equivalent to $100 \%$ maltose had been liberated, and that further conversion to glucose is entirely due to the maltase present as impurity, and not to the amylase itself. Reference to the two curves of Fig. 8 shows that, after the $100 \%$ maltose stage, the rates of liberation of further reducing groups were proportional to the maltase contents of the two preparations.

The complete conversion of starch to glucose by the combined action of the two enzymes was confirmed by isolation of glucosazone in $90 \%$ yield.

$100 \mathrm{ml} .5 \%$ starch paste were incubated at $37^{\circ}$ with $50 \mathrm{ml}$. (750 iodine-colour units) of a crude amylase preparation of high maltase content until hydrolysis was complete (96 $\mathrm{hr}$.). The solution was evaporated to dryness and extracted with boiling $90 \%$ ethanol as previously described (this, in addition to deproteinizing, removes any starch or higher dextrins). Glucosazone was isolated as before: yield, 4.5 g.; m.p. $207^{\circ}$, mixed m.p. $206.5^{\circ}$; found: C, 61.0; H, 6.3; $\mathrm{N}, 15 \cdot 0 \%$. No maltosazone was found.

Attempts to isolate maltose were only partially successful, owing to the difficulty of removing the last traces of maltase from the amylase. In one experiment $20 \mathrm{ml}$. of an amylase preparation of highest purity and lowest maltase content were incubated with $50 \mathrm{ml}$. of $5 \%$ starch paste, and the reaction stopped at an early stage (just before the iodine colour disappeared) in order to minimize conversion of maltose to glucose. On working up as before, only a small amount of glucosazone separated at $100^{\circ}$, and was filtered off on a hot funnel. From the filtrate about $1 \mathrm{~g}$. of an osazone, soluble in hot water, separated on cooling (no such osazone had been found in the previous experiment). Microscopic examination of the repeatedly recrystallized material showed it to consist mainly of crystals which from their shape were undoubtedly maltosazone, contaminated with amorphous material which could not be separated. This was probably the so-called 'iso-maltosazone' which is thought to be a mixture of osazones of short-chain dextrins.

\section{DISCUSSION}

Early workers on amylases believed their action to be a simple quantitative splitting of starch to maltose. Recent work (e.g. Hanes, 1937) has disclosed greater complexities in amylase action, and marked differences between amylases of different origin.
Malt $\alpha$-amylase, for example, forms no maltose at all and liberates only $33 \%$ of the theoretical reducing groups; the end-products are reducing dextrins, probably containing six glucose units, and giving no colour with iodine. Malt $\beta$-amylase, on the other hand, splits starch into maltose $(60 \%)$ and $\alpha$-amylodextrin, a non-reducing 12-unit dextrin giving a purple colour with iodine, which is not further attacked by the enzyme. The action of salivary and pancreatic amylases also ceases when less than the theoretical amounts of maltose (c. 80 and $65 \%$ respectively) are produced (Hanes \& Cattle, 1938). This cessation is not due to inactivation of the amylases, as addition of fresh enzyme has no effect; it is usually attributed to the formation of 'residue dextrins' not further attacked by the enzyme. Yet a fourth mode of action is displayed by the amylase of Aerobacillus macerans, which converts starch completely to non-reducing dextrins (of which the crystalline $\alpha$ - and $\beta$-dextrins of Schardinger are components), without formation of maltose or glucose, or liberation of reducing groups of any kind (Tilden \& Hudson, 1939).

The $C l$. acetobutylicum enzyme, however, seems to be an example of the (apparently rather rare) type of amylase which converts starch completely to maltose, with no other stable by-products. Hence the combined action of the amylase and maltase in Cl. acetobutylicum culture filtrates gives $100 \%$ conversion of starch to glucose. If short-chain dextrins are formed as intermediates, the enzyme is presumably capable of splitting them completely to maltose.

\section{SUMMARY}

1. Cell-free culture filtrates of $\mathrm{Cl}$. acetobutylicum contain an enzyme system which converts starch quantitatively to glucose.

2. This conversion is brought about by the successive action of two enzymes, an amylase and a maltase.

3. The properties of the enzymes are described. The amylase has been purified some 300 -fold.

This investigation was originally suggested by Dr Marjory Stephenson, to whom we wish to express our thanks. Dr C. S. Hanes invited us to publish the details of his method for determining reducing groups. We are grateful to him for allowing us to use the method, and for much useful advice. One of us (D. J. D. H.) thanks the Careswell Foundation for a research grant.

\section{REFERENCES}

Hanes, C. S. (1935). Biochem. J. 29, 2588.

Hanes, C. S. (1937). New Phytol. 36, 101.

Hanes, C. S. \& Cattle, M. (1938). Proc. Roy. Soc. B, 125, 387.

Holmbergh, O. (1933). Biochem. Z. 258, 134.

Robinson, G. C. (1922). J. biol. Chem. 53, 125.

Somogyi, M. (1931). J. biol. Chem. 90, 725.
Somogyi, M. (1937). J. biol. Chem. 117, 771.

Tilden, E. B. \& Hudson, C. S. (1939). J. Amer. chem. Soc. 61, 2900.

Tokuoka, Y. (1937). J. agric. chem. Soc. Japan, 13, 586.

Weizmann, C. \& Rosenfeld, B. (1937). Biochem. J. 31, 619. 